\title{
A Comparison of Moldboard Plows for Dry Season Tillage of Vertisols*
}

\author{
V.M. MAYANDE ${ }^{1}$, R.K. BANSAL ${ }^{2}$ and G.D. SMITH ${ }^{3}$ \\ International Crops Research Institute for the Semi-Arid Tropics (ICRISAT), Patancheru, \\ AP 502324 (India)
}

(Accepted for publication 12 September 1989)

\section{ABSTRACT}

V.M. Mayande, R.K. Bansal and G.D. Smith, 1990. A comparison of moldboard plows for dry season tillage of Vertisols. Soil Tillage Res., 15: 349-358.

Performance of five moldboard plows was compared during primary tillage in a dry Vertisol. The Kirloskar plow, which is commonly used on Vertisols in India, had the highest pull requirement; a sod bottom Brazilian plow had the next highest pull requirement, followed by the Triplex and ICRISAT plows. The general purpose Mouzon plow was the the easiest to pull. The Kirloskar plow created the roughest surface but in general the differences between plows in their effects on surface roughness and clod size are in practice probably not important for Vertisols.

\section{INTRODUCTION}

Vertisols are difficult soils for resource-poor farmers to manage. They tend to become very hard when dry and unworkable and sticky when wet, and their tillage often presents major problems. In traditional farming systems in India, these soils are cropped only once a year in the post-rainy season. A country plow and a blade harrow are generally used for seedbed preparation, but once every 3 or 4 years farmers plow with a reversible moldboard plow commonly known as the Kirloskar plow. This plow usually works 30 to $35 \mathrm{~cm}$ deep, requires two to four people and up to four pairs of bullocks to operate it and covers $0.02-0.03 \mathrm{ha} \mathrm{h}^{-1}$ (Anonymous, 1964). Improved soil management practices developed by ICRISAT allow crops to be grown both in the rainy and post-rainy seasons. In these practices, it is recommended that primary tillage

\footnotetext{
*Approved as ICRISAT journal article No. 888.

${ }^{1}$ Present address: Resource Management Program, CRIDA, Santoshnagar, Hyderabad, AP 500659 , India.

${ }^{2}$ Present address: MIAC Project, BP 290, Settat, Morocco.

${ }^{3}$ Author to whom correspondence should be addressed. Present address: Queensland Department of Primary Industries, PO Box 102, Toowoomba, Qld. 4350, Australia.
} 
start soon after harvest of the post-rainy season crops (Kampen, 1982). The objective of this early tillage is to use residual soil moisture to facilitate plowing. It removes most weeds and stubbles and creates a cloddy soil surface. The clods break down with weathering and further tillage for seedbed preparation before the onset of the monsoon. Deep plowing $(30-35 \mathrm{~cm})$ is not recommended in the improved systems but tillage to $10-15 \mathrm{~cm}$ is required. For some years there has been interest in developing effective, low-draft plows and a range of improved plow designs is now available.

This paper compares five types of moldboard plow. The plows were operated at two depths in a dry Vertisol to evaluate the effect of plow design features on pull requirement, clod size, and surface roughness of the soil.

\section{MATERIALS AND METHODS}

\section{Description of the plows tested}

The five types of moldboard plows studied are briefly described below and shown in Fig. 1.

The ICRISAT plow (Fig. 1a)

This plow was developed at ICRISAT for use on Vertisols. Its design is based on that of the Mouzon plow (Fig. 1d), but the moldboard has a generally cylindrical shape, with a slight twist at the end rather than an abrupt curvature. It has a $21.5-\mathrm{cm}$-wide general-purpose bottom, with a share made of high carbon steel. The weight of the plow bottom is $10.2 \mathrm{~kg}$. It is attached to an animaldrawn wheeled tool carrier. It requires one operator and one pair of bullocks and covers 0.09-0.13 ha h${ }^{-1}$ (Mayande et al., 1982). Bansal and Srivastava (1981) reported pull force requirement for a set of left- and right-hand plows in the range of $1.76-2.25 \mathrm{kN}$.

\section{The Triplex plow (Fig. 1b)}

This plow is similar to the ICRISAT plow, but it has a moldboard extension plate and a plow heel. The moldboard extension presumably gives better soil inversion. The triplex plow bottom is $21.5 \mathrm{~cm}$ wide and weighs $8.1 \mathrm{~kg}$.

\section{The Brazilian plow (Fig. 1c)}

This plow has a sod bottom ( $22.5 \mathrm{~cm}$ wide) with a long moldboard having a gradual twist designed to achieve complete inversion of the furrow slice with minimum breakup. This plow design is ideal for incorporating plant material. The plow bottom has a share made from chilled cast iron and weighs $10.4 \mathrm{~kg}$. 
The Mouzon (or Nole's) plow (Fig. 1d)

This plow was obtained from Mouzon S.A. (Mouzon, France) as an attachment to the Tropicultor (ICRISAT, 1985), made by the same firm. The Mouzon plow has an abrupt curvature near the rear top end of the moldboard. The plow bottom is $21.5 \mathrm{~cm}$ wide and weighs $9.0 \mathrm{~kg}$.

\section{The Kirloskar plow (Fig. 1e)}

This plow has a $17.5-\mathrm{cm}$ bottom with frog, share, and moldboard made of cast iron. The share has two wings and the moldboard surface is rather unusual, being convex at the centre. The plow bottom is attached to the frame through a hinge near the ground, and through an anchor to the moldboard. The plow bottom can be reversed by detaching the anchor and swinging it to the other side. The plow bottom alone weighs $17.7 \mathrm{~kg}$.

\section{Field tests}

The five moldboard plows described above were tested in a dry Vertisol at ICRISAT Centre, Patancheru, India. Physical properties of the soil are described elsewhere (El-Swaify et al., 1985). An experiment with three replications was conducted in a field where maize and chickpea had been grown on a flat land system in the previous season. Tillage, sowing, and interrow weeding of these crops had been carried out using a wheeled tool carrier (Tropicultor). The test plowings were done in March 1986 a few days after harvesting chickpea. Plot size was in the range of $150-190 \mathrm{~m}^{2}$, and each plot was divided into two subplots to test the plows at working depths of 10 and $15 \mathrm{~cm}$. For uniformity of operation and for good control of working depth, all the plows were mounted on special standards, which were attached to a Tropicultor.

Pull was measured using a dial type pull meter attached to the telescopic beam of the Tropicultor. Fifty or more readings of pull force were recorded in each plot to minimize the error due to fluctuations in the needle of the pull meter. The plowing depth was adjusted before the operation in an area outside the experiment. The depth of operation was measured in each pass with a device built by Alikhani (1981). The width of cut was measured with a measuring tape. Samples for soil moisture content were taken from 0 to 10 and 10 to $15 \mathrm{~cm}$ at the time of plowing.

Soil surface roughness was measured with a relief meter before and after plowing in the plots plowed to $15 \mathrm{~cm}$. The relief meter (Fig. 2) rested on pegs on the corners of a $1 \times 1.5 \mathrm{~m}$ area installed in each plot before plowing. The pegs were levelled using a dumpy level. The observations were taken at $5-\mathrm{cm}$ intervals along the $1.5-\mathrm{m}$ dimension, and at $15-\mathrm{cm}$ intervals along the $1-\mathrm{m}$ dimension. Soil surface roughness was calculated by the following formula (Allmaras et al., 1966; Lehrsch, 1985): 

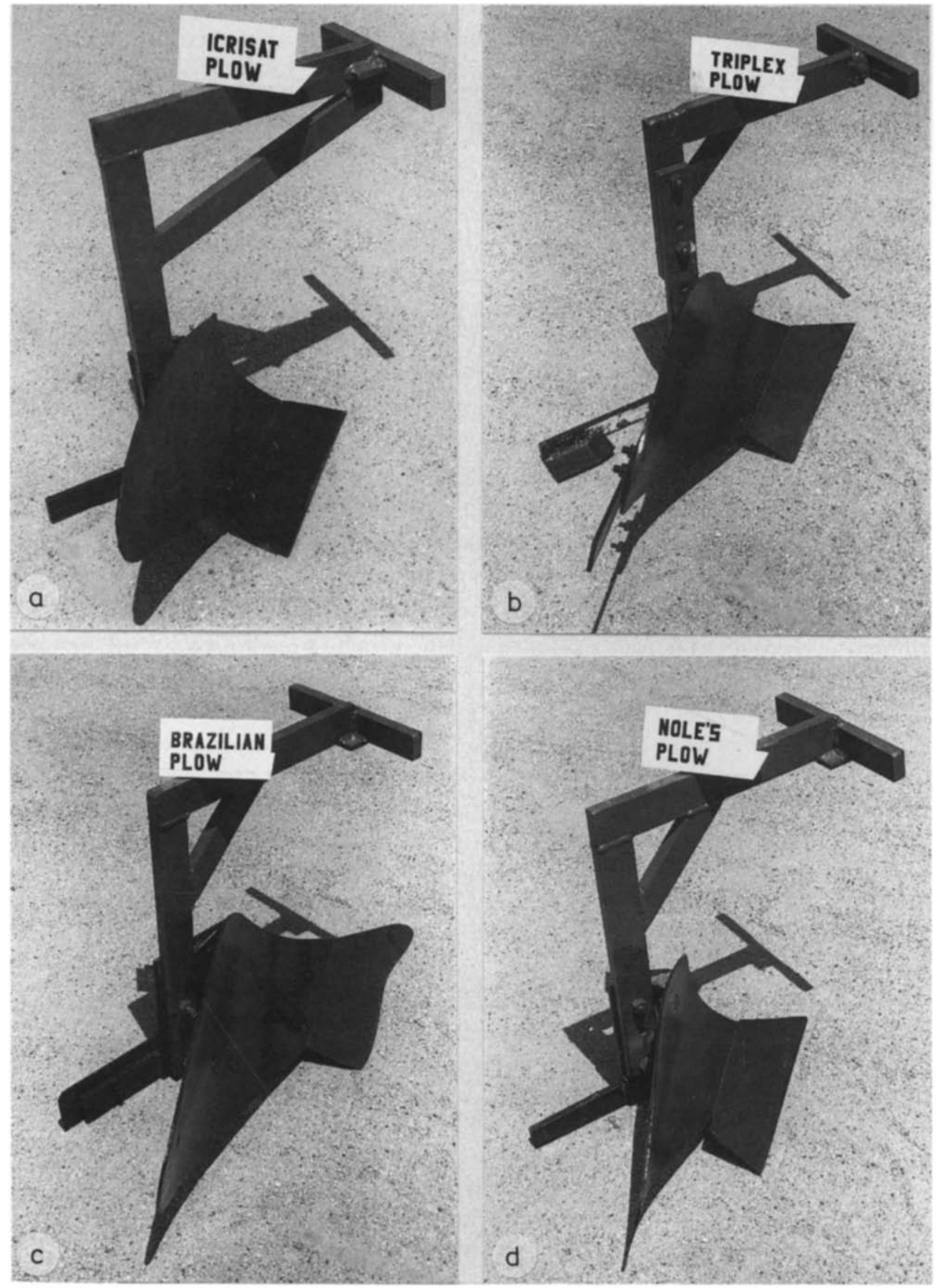


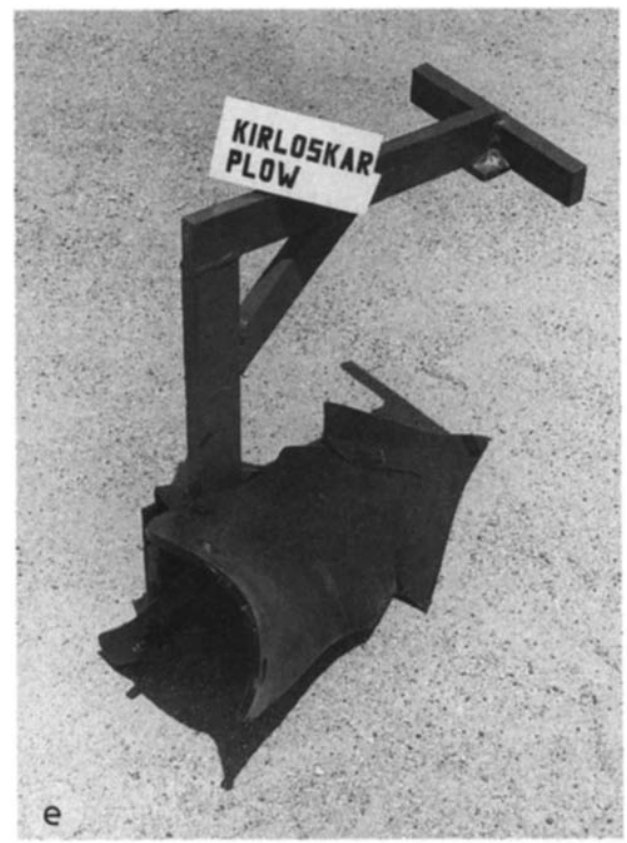

Fig. 1. The five plows as used in the tests: (a) ICRISAT plow; (b) Triplex plow; (c) Brazilian plow; (d) Mouzon (Nole's) plow; (e) Kirloskar plow.

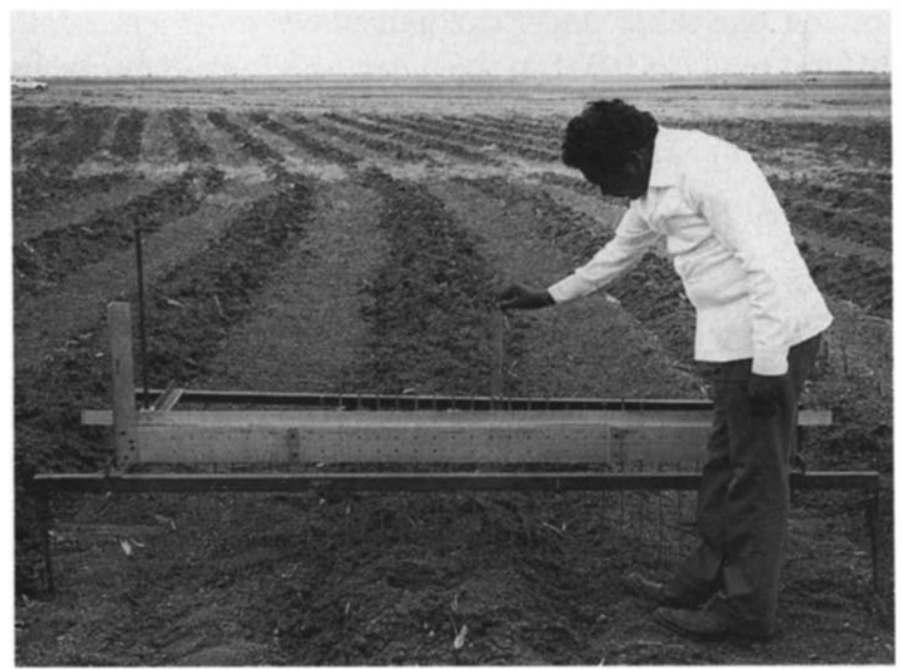

Fig. 2. Measuring surface roughness with a relief meter. 
$S=s h$

where: $S$ is defined as the random roughness index; $s$ is the standard error of the logarithms of height measurements; $h$ is the mean of the height measurements.

An index of plow type effects on clod size was obtained by sampling the plowed soil over an area of $1 \mathrm{~m}^{2}$ in each plot. All clods $>6 \mathrm{~cm}$ (approx.) in diameter were collected manually from the sample areas and weighed on an open-pan balance. In the calculation of relative clod size distribution, it was assumed that clods were spherical. It was also assumed that the bulk density of clods was $1.8 \mathrm{~g} \mathrm{~cm}^{-3}$ and that water content was uniform. These assumptions are justified because the calculated clod diameter changes less than $10 \%$ for a change in clod bulk density from 1.5 to $1.9 \mathrm{~g} \mathrm{~cm}^{-3}$. Mean weight diameter (MWD) of the clods collected was calculated using the following formula (Kemper and Chepil, 1965)

$\mathrm{MWD}=X_{\mathrm{i}} W_{\mathrm{i}}$

where: $X_{\mathrm{i}}$ is the mean diameter of each size fraction; $W_{\mathrm{i}}$ is the proportion of the total sample weight occurring in the corresponding size fraction.

Twenty size fractions in the clod diameter range $6-19 \mathrm{~cm}$ were used to calculate the MWD.

\section{RESULTS AND DISCUSSION}

\section{Pull Requirement}

With the exception of the Kirloskar and Brazilian plows at 15-cm depth there were significant differences $(P>0.05)$ in the mean pull force required by the five plows at both working depths (Table 1). The mean pull force for a working depth of $10 \mathrm{~cm}$ was in the order

Mouzon $<$ ICRISAT $<$ Triplex $<$ Brazilian $<$ Kirloskar.

For a working depth of $15 \mathrm{~cm}$ the order was

Mouzon $<$ ICRISAT $<$ Triplex $<$ Kirloskar $<$ Brazilian.

In terms of specific pull, the Kirloskar plow was clearly the heaviest and the Mouzon plow the lightest. The Brazilian plow was intermediate between these two, while the ICRISAT and Triplex plows were slightly heavier than the Mouzon. The shape of the moldboard and the share edge shape influence draft (Kepner et al., 1982), though the relative effects are influenced by soil condition, speed, and perhaps other factors. The Kirloskar plow has a convex moldboard surface, and this may be the cause of its higher draft requirement. The ICRISAT, Mouzon, and Triplex plows have only slight differences in the shapes 
TABLE 1

Pull force requirement and related observations for five types of moldboard plow

\begin{tabular}{|c|c|c|c|c|c|c|c|c|}
\hline \multirow[t]{2}{*}{ Type of plow } & & \multicolumn{2}{|l|}{ Pull } & \multirow{2}{*}{$\begin{array}{l}\text { Soil } \\
\text { moisture } \\
(\%)\end{array}$} & \multirow{2}{*}{$\begin{array}{l}\text { Average } \\
\text { width of } \\
\text { cut } \\
(\mathrm{cm})\end{array}$} & \multirow{2}{*}{$\begin{array}{l}\text { Average } \\
\text { depth of } \\
\text { plowing } \\
(\mathrm{cm})\end{array}$} & \multirow{2}{*}{$\begin{array}{l}\text { Cross- } \\
\text { section } \\
\text { area } \\
\left(\mathrm{cm}^{2}\right)\end{array}$} & \multirow{2}{*}{$\begin{array}{l}\text { Specific } \\
\text { pull } \\
\left(\mathrm{N} \mathrm{cm}^{-2}\right)\end{array}$} \\
\hline & & $\begin{array}{l}\text { Range } \\
(\mathrm{kN})\end{array}$ & $\begin{array}{c}\text { Mean } \\
(\mathrm{kN})\end{array}$ & & & & & \\
\hline \multirow[t]{2}{*}{ ICRISAT } & D1 & $1.1-3.5$ & 2.10 & 5.9 & 20.5 & 10.2 & 209 & 10.0 \\
\hline & D2 & $1.2-3.7$ & 2.47 & 9.4 & 19.5 & 13.4 & 261 & 9.4 \\
\hline \multirow[t]{2}{*}{ Triplex } & D1 & $1.4-3.3$ & 2.33 & 6.2 & 21.0 & 11.1 & 233 & 10.0 \\
\hline & D2 & $1.9-4.7$ & 3.65 & 8.7 & 21.0 & 14.8 & 310 & 11.6 \\
\hline \multirow[t]{2}{*}{ Brazilian } & D1 & $1.9-3.9$ & 3.09 & 5.2 & 18.4 & 11.2 & 206 & 14.9 \\
\hline & D2 & $2.9-4.9$ & 4.29 & 7.3 & 15.1 & 15.3 & 231 & 18.5 \\
\hline \multirow[t]{2}{*}{ Mouzon } & D1 & $1.0-1.9$ & 1.47 & 5.6 & 18.9 & 10.3 & 194 & 7.5 \\
\hline & D2 & $1.4-2.7$ & 2.01 & 6.8 & 18.9 & 15.3 & 289 & 7.0 \\
\hline \multirow[t]{2}{*}{ Kirloskar } & D1 & $1.9-4.9$ & 4.08 & 6.2 & 12.1 & 10.6 & 128 & 31.7 \\
\hline & D2 & $3.6-4.7$ & 4.11 & 8.8 & 9.1 & 14.6 & 132 & 30.7 \\
\hline \multirow[t]{2}{*}{ SE $( \pm)$} & D1 & & 0.08 & 0.19 & 1.59 & 0.20 & - & 4.39 \\
\hline & $\mathrm{D} 2$ & & 0.07 & 0.49 & 2.14 & 0.35 & - & 4.27 \\
\hline
\end{tabular}

D1 is $10-\mathrm{cm}$ and D2 is $15-\mathrm{cm}$ depth of plowing.

of their moldboards and shares. Nevertheless these minor differences in design are sufficient to vary the specific pull requirement from 7 to $11.6 \mathrm{~N} \mathrm{~cm}^{-2}$ at $15-\mathrm{cm}$ depth of working.

\section{Clod Size}

Mean weight diameters of clods collected and significant differences between plows are shown in Table 2.

It may be seen from Table 2 that MWD ranged from $9.72 \mathrm{~cm}$ to $12.63 \mathrm{~cm}$ for the $10-\mathrm{cm}$ working depth, and from $11.09 \mathrm{~cm}$ to $12.76 \mathrm{~cm}$ for the $15-\mathrm{cm}$ depth. Thus although some plows had statistically significant effects on clod size, the actual difference was not large and when the plows are used for primary tillage these differences probably would not be important. Further study is needed to clarify this aspect.

Coughlan (1984) reported that aggregate size in Vertisols following wetting and drying is strongly influenced by rate and extent of wetting, and temperature of drying. The soil moisture content at plowing was between 5 and $6 \%$ at $10-\mathrm{cm}$ depth and 7 and $9 \%$ at $15-\mathrm{cm}$ depth (Table 1 ). At these relatively low water contents, aggregates would have been strong and noncohesive and it is unlikely that the plows could have formed aggregates or clods by compression. We hypothesize that clods were formed by the plows breaking up the soil along 


\section{TABLE 2}

Relative mean weight diameter (MWD) of clods formed during plowing at $10-\mathrm{cm}$ and $15-\mathrm{cm}$ depths

\begin{tabular}{lcl}
\hline Type of the plow & $10-\mathrm{cm}$ depth & $15-\mathrm{cm}$ depth \\
\hline ICRISAT & $9.72^{\mathrm{d}}$ & $11.37^{\mathrm{bc}}$ \\
Triplex & $12.24^{\mathrm{b}}$ & $12.45^{\mathrm{a}}$ \\
Brazilian & $10.57^{\mathrm{c}}$ & $11.09^{\mathrm{c}}$ \\
Mouzon & $12.03^{\mathrm{b}}$ & $12.76^{\mathrm{a}}$ \\
Kirloskar & $12.63^{\mathrm{a}}$ & $11.53^{\mathrm{b}}$ \\
SE $( \pm)$ & 0.100 & 0.118 \\
Mean & 11.44 & 11.84 \\
LSD $(0.05)$ & 0.326 & 0.385 \\
\hline
\end{tabular}

Figures with common letter are not significantly different at $P<0.05$.

TABLE 3

Soil surface roughness index before and after plowing plots to $15 \mathrm{~cm}$

\begin{tabular}{llll}
\hline Type of plow & Before plowing & After plowing & Difference \\
\hline ICRISAT & 0.11 & 0.45 & 0.25 \\
Triplex & 0.12 & 0.37 & 0.25 \\
Brazilian & 0.15 & 0.41 & 0.26 \\
Mouzon & 0.19 & 0.42 & 0.23 \\
Kirloskar & 0.14 & 0.62 & 0.48 \\
SE $( \pm)$ & 0.01 & 0.04 & 0.05 \\
Mean & 0.14 & 0.45 & 0.31 \\
\hline
\end{tabular}

failure planes or lines of weakness formed in the last drying cycle. According to this hypothesis the implement effect would have been superimposed on the pre-existing effect of the aggregation process. The overall mean clod size was similar for both depths of plowing. This further supports the above hypothesis that the major effect of the design of the moldboard was on rearranging preexisting aggregates. The work of Wolf and Hadas (1987) offers further support. They compared six moldboard plows on a dry Vertisol and attributed the minor differences they found to similar soil structural factors.

\section{Surface roughness}

Surface roughness is important to trap runoff. The roughness index increased sharply as a result of plowing (Table 3). The Kirloskar plow gave a significantly greater increase in the surface roughness index than all other 
plows, despite the fact that clod size was significantly higher for the Mouzon and Triplex plows. The roughness index is an indication of how the plows have sorted and rearranged the aggregates. It would reflect the action of the moldboard in inverting, mixing and spreading the shattered soil. The Kirloskar plow evidently creates a surface microrelief that is quite independent of clod size. This may be why it has been favored by farmers. Plows leaving a relatively smooth soil surface would give better soil coverage of inverted weeds, but they may give less surface detention storage for trapping runoff.

\section{Factors in choice of a plow for Vertisols}

Both clod formation and surface roughness index results indicate that a sod bottom such as that of the Brazilian plow does not offer any particular advantage for a dry Vertisol and it has a high specific pull requirement. Goyal and Drew Leland (1979) reported that the draft of an average plow bottom constitutes $18 \%$ pulling, $48 \%$ cutting the furrow slice, and $34 \%$ turning over the slice. The Kirloskar plow is not a good design (unless the need for a rough surface outweighs other considerations) because it requires a very high pull force, probably because the energy needed for both cutting and turning of the furrow slice is high. The Mouzon plow appears to be the best among the plows tested because it has the lowest pull requirement and the plowing effect is generally comparable with that of the other plows. The Mouzon plow has a cutting edge and overall dimensions similar to those of the ICRISAT and the Triplex plows. We consider that it is the difference in shape of the moldboard that reduced the pull requirement of the Mouzon plow and gave relatively large mean clod size.

\section{CONCLUSIONS}

Various conclusions can be drawn from this study.

(1) Despite its common use by farmers, the Kirloskar plow has a relatively high pull requirement $(4.1 \mathrm{kN})$ even at shallow working depths in a dry Vertisol. The relatively high specific pull requirement of this plow is attributed to the design of the cutting edge, and the converse moldboard shape. The results clearly suggest that the Kirloskar plow could be replaced by a better design that would save energy and time.

(2) The sod bottom gives the Brazilian plow a relatively high pull requirement ( $3.1 \mathrm{kN}$ and $4.3 \mathrm{kN}$ for $10-\mathrm{cm}$ and $15-\mathrm{cm}$ working depths, respectively). No significant advantage was apparent from plowing a dry Vertisol with a sod bottom in terms of pulverization and soil surface roughness.

(3) The general-purpose bottom of the Mouzon plow was the easiest to pull. The effect of plowing with a Mouzon plow was comparable with the other plows.

(4) Although the formation of clods and the soil surface roughness left by 
the ICRISAT and the Triplex plows did not differ significantly from the Mouzon plow, it appears that there were differences in the way these plows acted to cut the furrow slice, as these plows had higher pull requirements than the Mouzon plow.

(5) There is a need for research to determine more precisely what soil conditions dry-season tillage of Vertisols should aim to produce. It is likely that these would vary with rainfall regions and natural soil structural tendencies (especially self-mulching capacity of the soil). With a better understanding of tiliage objectives, a better designed plow can enable easier and more effective land preparation.

\section{REFERENCES}

Alikhani, Z., 1981. Draft measurements in an Alfisol and a Vertisol under two management systems. M.E. thesis, Asian Institute of Technology, Bangkok, Thailand, 71 pp.

Allmaras, R.R., Burwell, R.E., Larson, W.E., Holt, R.F. and Nelson, W.W., 1966. Total porosity and random roughness of the interrow zone as influenced by tillage. USDA Conserv. Res. Report No. 7. U.S. Government Printing Office, Washington, DC.

Anonymous, 1964. The shabash story. Agricultural Development Society, Naini, Allahabad, India.

Bansal, R.K. and Srivastava, K.L., 1981. Improved animal drawn implements for farming in the semi-arid tropics. Agric. Mech. Asia, Africa, Latin Am., 12(1): 33-38.

Coughlan, K.J., 1984. The structure of Vertisols. In: J.W. McGarity, E.H. Hoult and H.B. So (Editors), Proceedings of a Symposium on the Properties and Utilisation of Cracking Clay Soils. Reviews in Rural Science no. 5. University of New England, Armidale, N.S.W. pp. 8796.

El-Swaify, S.A., Pathak, P., Rego, T.J. and Singh, S., 1985. Soil management for optimised productivity under rainfed conditions in the semi-arid tropics. Adv. Soil Sci., 1: 1-64.

Goyal, Megh R. and Drew Leland, O., 1979. Chisel plowing vs. moldboard plowing. Agric. Mech. Asia, Africa, Latin Am., 10(4): 51-56.

ICRISAT (International Crops Research Institute for the Semi-Arid Tropics), 1985. The Tropicultor Operators' manual: field operations. ICRISAT, Patancheru, 502 324, Andhra Pradesh, India, $64 \mathrm{pp}$.

Kampen, J., 1982. Management of rainwater and technology transfer. In: Symposium on Rainwater and Dryland Agriculture, 3 Oct 1980, New Delhi, India: Indian National Science Academy, pp. 34-53.

Kemper, W.D. and Chepil, W.S., 1965. Size distribution of aggregates. In: C.A. Black (Editor), Methods of Soil Analysis, Part II, Agronomy 9. American Society of Agronomy, Madison, WI, pp. 499-510.

Kepner, R.A., Bainer, R. and Barger, E.L., 1982. Principles of Farm Machinery, 3rd edn. The Avi Publishing Company Inc. Westport, CT, pp. 136-159.

Lehrsch, G.A., 1985. Soil surface roughness as affected by rainfall, cultivation, and crop canopy development. Ph.D. thesis. Mississippi State University, Available from University Microfilms International, Ann Arbor, MI, 76 pp.

Mayande, V.M., Thierstein, G.E., Sarin, R., Sanghi, N.K. and Kidd, D.W., 1982. A technical evaluation of improved animal drawn implements under on-farm conditions. Presented at the Second Annual Convention of the Andhra Pradesh Chapter of the Indian Society of Agricultural Engineers, 7 Jan 1982, Hyderabad, India. ICRISAT, Andhra Pradesh, India. 18 pp.

Wolf, D. and Hadas, A., 1987. Determining efficiencies of various moldboard ploughs in fragmenting and tilling air-dry soils. Soil and Tillage Res., 10: 181-190. 